\title{
Life-cycle and freshwater withdrawal impact assessment of water supply technologies
}

Godskesen, Berit; Hauschild, Michael Zwicky; Rygaard, Martin; Zambrano, K.; Albrechtsen, Hans-Jørgen

Published in:

Water Research

Link to article, DOI:

10.1016/j.watres.2013.02.005

Publication date:

2013

Link back to DTU Orbit

Citation (APA):

Godskesen, B., Hauschild, M. Z., Rygaard, M., Zambrano, K., \& Albrechtsen, H-J. (2013). Life-cycle and freshwater withdrawal impact assessment of water supply technologies. Water Research, 47(7), 2363-2374. https://doi.org/10.1016/j.watres.2013.02.005

\section{General rights}

Copyright and moral rights for the publications made accessible in the public portal are retained by the authors and/or other copyright owners and it is a condition of accessing publications that users recognise and abide by the legal requirements associated with these rights.

- Users may download and print one copy of any publication from the public portal for the purpose of private study or research.

- You may not further distribute the material or use it for any profit-making activity or commercial gain

- You may freely distribute the URL identifying the publication in the public portal 


\section{Life-cycle and freshwater withdrawal impact assessment of water supply technologies}

2 B. Godskesen ${ }^{a, b,},{ }^{*}$, M. Hauschild ${ }^{c}$, M. Rygaard ${ }^{a}$, K. Zambrano $^{b}$, H.-J. Albrechtsen ${ }^{a}$

3 a Technical University of Denmark, Department of Environmental Engineering, Miljøvej, Building 113,

42800 Lyngby, Denmark ("Corresponding author, e-mail:berg@env.dtu.dk, phone: 00452795 4670)

$5 \quad{ }^{\mathrm{b}} \mathrm{HOFOR}, \varnothing$ restads Boulevard 35, 2300 København S, Denmark

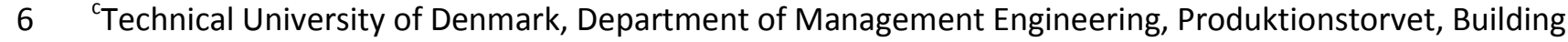

$7 \quad 424,2800$ Lyngby, Denmark

\section{Abstract}

9 Four alternative cases for water supply were environmentally evaluated and compared based on the standard environmental impact categories from the life-cycle assessment (LCA) methodology extended

11 with a freshwater withdrawal category (FWI). The cases were designed for Copenhagen, a part of

12 Denmark with high population density and relatively low available water resources. FWI was applied at

13 local groundwater catchments based on data from the national implementation of the EU Water

14 Framework Directive. The base case of the study was the current practice of groundwater abstraction

15 from well fields situated near Copenhagen. The 4 cases studied were: Rain \& stormwater harvesting

16 from several blocks in the city; Today's groundwater abstraction with compensating actions applied in

17 the affected freshwater environments to ensure sufficient water flow in water courses; Establishment of

18 well fields further away from the city; And seawater desalination. The standard LCA showed that the

19 Rain \& stormwater harvesting case had the lowest overall environmental impact $\left(81.9 \mu \mathrm{PET} / \mathrm{m}^{3}\right)$

20 followed by the cases relying on groundwater abstraction (123.5-137.8 $\left.\mu \mathrm{PET} / \mathrm{m}^{3}\right)$, and that desalination

21 had a relatively small but still important increase in environmental impact $\left(204.8 \mu \mathrm{PET} / \mathrm{m}^{3}\right)$. Rain \&

22 stormwater harvesting and desalination had a markedly lower environmental impact compared to the 
23 base case, due to the reduced water hardness leading to e.g. a decrease in electricity consumption in

24 households. For a relevant comparison, it is therefore essential to include the effects of water hardness

25 when comparing the environmental impacts of water systems of different hardness. This study also

26 emphasizes the necessity of including freshwater withdrawal respecting the relevant affected

27 geographical scale, i.e. by focusing the assessment on the local groundwater catchments rather than on

28 the regional catchments. Our work shows that freshwater withdrawal methods previously used on a

29 regional level can also be applied to local groundwater catchments and integrated into the standard LCA

30 as an impact category. When standard LCA is extended to include impacts of freshwater withdrawal,

31 rain \& stormwater and seawater (0.09-0.18 compared to $\left.11.45-17.16 \mathrm{mPET} / \mathrm{m}^{3}\right)$ were the resources

32 resulting in least overall environmental impact.

\section{Keywords}

34 Life-cycle assessment; Freshwater withdrawal impact; Groundwater abstraction; Rain \& stormwater 35 harvesting; Desalination; Water hardness 


\section{Introduction}

Conflicts over water have been occurring since the beginning of time. Even though the Danish capitol Copenhagen is usually not considered as being in water shortage, water use is currently sowing the seeds of dispute. Industry, agriculture and urban water supply are the main activities responsible for withdrawing water from the natural environment. The purity of groundwater is acknowledged in the region and most water consuming activities are based on this resource.

The European Water framework directive (EU-WFD) is being implemented in the EU-Member States by the River Basin Management Plans which among other parameters regulate the water flow requirements for water flows and the utilizable amount of water in each freshwater (ground and surface water) compartment (European Union, 2000). The implementation has revealed that groundwater is not an abundant resource as often believed (European Environment Agency, 2007), and the water utility HOFOR has been forced to seek new water resources or new approaches to sustain the water withdrawal permissions in order to supply the City with sufficient water for urban purposes. This has led to the identification of 4 relevant cases for water supply which fulfill the EU-WFD and which either alone or as a mix can constitute the future water supply.

In this study we performed an environmental evaluation of the 4 cases for water supply since environmental performance is a well established criterion and should per se be included in any evaluation of future supply options and in our search for the optimal water supply option. One way to evaluate the environmental performance is to use life-cycle assessment (LCA) which has proven its strengths for evaluating water systems environmentally by using a "cradle-to-grave" approach (Lundie et al., 2004; Lyons et al., 2009; Godskesen et al., 2011; Schulz et al., 2012). LCA can also include effects of reduced water hardness in the households which are relevant when evaluating water systems of different water hardness (Godskesen et al., 2012). However, the impacts of a product or system on freshwater resources are not included in the current typical LCA practice. Many have previously 
expressed the volume of freshwater withdrawn for water supply (Sharma et al., 2009; Lundie et al.,

61 2004) e.g. by water foot-printing (Hoekstra et al., 2011) where water is considered a resource for man

62 rather than an environmental media with environmental impacts when withdrawn. Recently methods

63 have been suggested to integrate freshwater use into the LCA methodology by treating freshwater

64 withdrawal as an environmental impact category with an impact on the freshwater environment (Muñoz

65 et al., 2010; Milà-i-Canals et al., 2009; Lévová \& Hauschild, 2011; Zelm et al., 2010; Pfister et al., 2009;

66 Kounina et al., 2012).

67 In our study we adopted the method of Lévová \& Hauschild (2011) for integrating freshwater

68 withdrawal into the standard LCA and further developed it by applying the method to the local level of

69 groundwater compartments via regulations and data in the national implementation of the EU-WFD. We

70 chose the method because it has modest data requirements that can be fulfilled both at regional and

71 local scale. It calculates the characterization factor (CF) which is a part of the freshwater withdrawal

72 impact (FWI) based on water resource measures (Milà-i-Canals et al., 2010; Muñoz et al., 2010; Pfister et

73 al., 2009) as opposed to native species occurrence (Zelm et al., 2010). We also applied normalization

74 and weighting according to the local level and in accordance with the LCA methodology converting

75 freshwater withdrawal impact to the same metric as the standard environmental LCA categories. Our

76 method only considers freshwater withdrawal as an impact since saline water is not in shortage. Most of

77 the Earth's water is present in the oceans as saline water and only $2.5 \%$ is freshwater. Icecaps and

78 glaciers make up 69\% of Earth's freshwater leaving 31\% as directly available ground and surface water

79 (Gleick, 2000). It is our hope that in future environmental evaluations of water consuming products or

80 systems, freshwater withdrawal will be given the attention it deserves, and this is our suggestion of how

81 to address it. 
82 The aim of this study is to compare the environmental impact of 4 cases for water supply and include

83 the impacts of freshwater withdrawal.

\section{Material and methods}

$85 \quad 2.1$ Life-cycle assessment

86 A standard LCA (ISO, 2006) generally consists of 4 phases: 1 . Goal and scope definition, 2. Inventory

87 analysis, 3. Impact assessment and 4. Interpretation. Prior to the LCA we went through each phase in

88 relationship to our study.

\section{$89 \quad$ 2.1.1 Goal and scope definition}

90 The defined goal was to assess the environmental impacts of 4 cases for water supply all tailored to

91 fulfill the requirements of the EU-WFD. Thereby the goal allowed for ranking the cases according to their

92 environmental performance. The functional unit was production of water which fulfilled the EU-WFD's

93 water flow requirements for water courses where freshwater was withdrawn and replacing $1 \mathrm{~m}^{3}$ of

94 potable drinking water as produced today. The produced water could be potable or non-potable

95 depending on the use of the drinking water that it replaces.

96 The system boundaries were the same for all cases (Figure 1): 1) Intake, withdrawal or harvest of water

97 from a source which was groundwater, rain \& stormwater or seawater; 2) Treatment facilities such as

98 waterworks, desalination plant and rainwater basins, pumps, electricity consumption and auxilliary

99 chemical consumption during water treatment were included; 3) Distribution to consumers' taps via

100 piped distribution system including the effects in the households caused by an altered water quality e.g.

101 reduced water hardness for the 2 cases with lower concentration of calcium and magnesium; 4)

102 Transport of wastewater to the wastewater treatment plant (WWTP) for treatment via the City's

103 combined sewer system before discharging to the sea (Øresund). Only electricity consumption at the

104 WWTP was included since other impacts from this activity are of minor importance (Lundie et al., 2004; 
Danva, 2010) and since the discharged water was assumed to contain the same pollutants for all cases

106 and hence would not affect the comparison of the cases. An average grid mix was developed for

107 electricity consumption based on electricity production data from 2010 in Denmark consisting of 56\%

108 hard coal, $23 \%$ wind power, $20 \%$ natural gas and $1 \%$ heavy fuel oils. In the sensitivity analysis it was

109 investigated how an alternative energy mix according to Danish governmental predictions on future

110 scenarios for electricity mix would affect the results. Table 1 and section 2.3 contain details of each case.

\section{$111 \quad 2.1 .2$ Inventory}

112 On the input side, the life-cycle inventory consisted of materials, chemicals and energy input primarily

113 based on data from the water utility in Copenhagen (HOFOR) and otherwise most accurate data

114 estimations from literature. All material and energy inputs were determined based on the functional

115 unit. The PE database as offered by PE Consulting group was used and when pre-developed processes

116 were not found of sufficient accuracy processes were developed according to local data estimations, e.g.

117 electricity mix for Denmark.

\section{$118 \quad 2.1 .3 \quad$ Impact assessment}

119 The LCA was performed with the GaBi 4.4 software developed by PE International according to the ISO

12014044 standard procedure (ISO, 2006) with the exception that a weighting step was performed. Impacts

121 were assessed with the EDIP 1997 method which is a standardized LCA method initially developed for

122 the Environmental Design of Industrial Products (Wenzel et al., 1997) but also found applicable for

123 services such as drinking water supply (Godskesen et al., 2011). The impact assessment covered the

124 steps classification and characterization, normalization and weighting. Classification meant sorting all

125 substance flows in the LCA according to their impacts on the environment. In the characterization step

126 the intensity of the impacts was determined by multiplying the quantities of a substance flow by its

127 characterization factor (CF), which expresses the potential impact of the flow on a per unit level.

128 Normalization brought all impact scores on a common scale by dividing each of them by the 
corresponding normalization reference representing an average European citizen's annual contribution

within each impact category. Hereby all the impacts were expressed in person equivalents, representing

131 the impact of consuming $1 \mathrm{~m}^{3}$ water relative to a person's total annual impact on the environment. The

132 result of the LCA is presented in impact categories within the EDIP method which is a midpoint method

133 (Hauschild \& Potting, 2005). Finally, the normalized impact scores were weighted using weighting

134 factors that for the environmental impacts are based on the distance from current levels of impact to

135 the European or Global politically set targets within each impact category (Stranddorf et al., 2005). For

136 resource impacts the weighting is based on the scarcity of the resource. After weighting, all

137 environmental impacts can be summed and so can all resource impacts. The weighting expresses the

138 environmental impacts in targeted person equivalents (PET) - the annual impact that can be caused by

139 an average citizen in accordance with the current political targets. The resource impacts are expressed

140 as person reserves (PR) - the amount of the resource available in the currently known extractable

141 reserves per person in the world today. We based the comparison of the 4 cases on 4 environmental

142 impact categories: Global warming, Acidification, Nutrient enrichment and Photochemical ozone

143 formation. Likewise, 3 chemical related toxicity categories were included: Chronic ecotoxicity in water,

144 Human toxicity via soil and Human toxicity via water. Resource consumption was also evaluated for the

145 relevant resources.

$146 \quad 2.2$ Freshwater withdrawal impact

147 The environmental impacts of withdrawing freshwater are not represented by any of the impact

148 categories, and in order to support inclusion of these potentially important impacts we modified the

149 water use impact method developed for industry by Lévová \& Hauschild (2011) by applying it to local

150 groundwater catchments. The method was further integrated into the LCA by adding both a

151 normalization and weighting step in accordance with the EDIP methodology. This allowed for 
152 comparison with the already established LCA impact categories since we considered freshwater

153 withdrawal an environmental impact in accordance with e.g. global warming.

154 The Freshwater withdrawal impact was reflected in the impact score FWI calculated by multiplying the

155 volume of water withdrawn by each case $\left(Q, \mathrm{~m}^{3}\right)$ by the characterization factor for the freshwater

156 withdrawal impact on the ecosystem (CF) representing the sensitivity of freshwater ecosystems towards

157 freshwater withdrawal on a local level. Within the 4 phases of a standardized LCA the FWI method

158 involved 3 special considerations since the FWI is not yet standardized: 1) Quantification from a life-

159 cycle perspective of groundwater volume withdrawn to produce the functional unit; 2) Determination of

160 characterization factors; and 3) Normalization and weighting.

\section{$161 \quad$ 2.2.1 Quantification of freshwater withdrawn}

162 The withdrawal of freshwater (Q) was quantified in the inventory of the LCA. Since this case is about

163 water production both water withdrawn for water supply and water used throughout the life-cycle was

164 included. In the city combined sewers lead rain \& stormwater to the wastewater treatment plants

165 where it after treatment is discharged into the Sea. Since the precipitation does not infiltrate and

166 increase the groundwater recharge the volumes withdrawn for production were not included for cases

167 based on rain \& stormwater as well as seawater.

168 We assumed that the water used throughout the life-cycle originated from local groundwater. Water

169 leaving the production or returned to the same local water catchment after treatment was deducted.

\section{$170 \quad$ 2.2.2 Characterization factor}

171 In the characterization step the freshwater use impact was converted into its potential impact on the

172 freshwater environment. The Characterization factor (CF) was calculated as follows:

$173 \quad C F=\left(\frac{W U}{W R-E W R}\right)^{(W R /(2 x E W R))}$

(Lévová \& Hauschild, 2011) 
174 The water use (WU), water resource (WR) and environmental water requirements (EWR), $\left[\mathrm{km}^{3} / \mathrm{y}\right]$, were

175 extracted from the local EU-WFD plan for areas where HOFOR had well fields and only groundwater was considered for the CF. A general EWR was stated by the Danish EPA as $65 \%$ of WR for the whole country

177 without consideration of the specific site. This is considered a precautionary decision and primarily

178 applicable for comparison of exploitation among groundwater catchments (Danish Nature Agency,

179 2011). This relatively high EWR has been estimated lower (35\%) for the surface and groundwater catchments in the region (Smakhtin et al., 2004). We applied 65\% of WR for EWR as the default and

181 tested the application of a lower EWR in our sensitivity analysis. CFs were calculated for all local water 182 catchments identified in the EU-WFD plans and a weighted average representing the total abstraction of 183 HOFOR was calculated according to the volume withdrawn in each region. Hereby CFs were based on 184 local measures of sensitivity of freshwater withdrawal and FWI was characterized to express the 185 contribution to the standard environmental impacts from water withdrawal.

\section{$186 \quad$ 2.2.3 Normalization and weighting}

187 The results for FWI were normalized by dividing with the normalization reference for the local area as 188 water use impacts are generally considered depending on the local conditions (Lévová \& Hauschild, 189 2011). Development of a regional normalization reference was done by multiplying the total water 190 withdrawal originating from groundwater with the regional CF and dividing by the region's population 191 (Statistics Denmark, 2012) thereby obtaining a reference for an average citizen in this area. The total 192 groundwater withdrawal in the region is reported each year to a national water database (Danish 193 Geological Survey, 2012) gathering withdrawals from water supplies, industries, agriculture, etc. The 194 normalization step converted FWI into the common metric PE (person equivalent) as the other 195 environmental impact categories within the LCA. The last step was weighting where the seriousness of 196 the impact category is multiplied by a weighting factor. Since there is no weighting factor in the EDIP-

197 method for freshwater withdrawal yet, the minimum importance 1 (representing no political reduction 
targets for the impact) was assumed for FWI. For comparison the weighting for the global warming

199 impact category is 1.3. The low weight of FWI opens for investigation of the importance of FWI. A lower

200 weighting can only occur if another approach other than distance to target is applied. The weighting

201 allows for aggregation of FWI with the other weighted environmental impact categories of the LCA.

\section{$202 \quad 2.3$ Description of the cases}

203 We identified 4 hypothetical cases for water supply of relevance for Copenhagen in the search for the

204 optimal water supply technology which fulfills the EU-WFD's water flow requirements and replaces $1 \mathrm{~m}^{3}$

205 of potable drinking water as of today. The 4 cases were: A1 rain \& stormwater harvesting, A2

206 compensating actions, A3 new well fields and A4 desalination. The existing system was also included, A0

207 base case. A0 enabled us to compare the environmental impacts and FWI of the 4 cases with today's

208 water production. See Supplementary material I for inventory of LCA and FWI of the 4 cases.

\subsubsection{A0 Base case}

210 In 2009 the City of Copenhagen (population of 0.52 million) used a total volume of 29.8 million $^{3}$

211 drinking water. The water is abstracted from groundwater sources located outside the city and requires

212 only simple treatment at the waterworks in terms of aeration and sand filtration before distribution.

213 During aeration $\mathrm{CH}_{4}$ and $\mathrm{H}_{2} \mathrm{~S}$ were emitted and these are included in the LCA. The water abstraction,

214 treatment and distribution consume only $0.27 \mathrm{kWh}$ per $\mathrm{m}^{3}$ drinking water. Since the groundwater

215 originates from chalk aquifers the hardness is $362 \mathrm{mg} / \mathrm{L}$ as $\mathrm{CaCO}_{3}$ and categorized as very hard drinking

216 water (US Geological Survey, 2012). Actual data on materials and consumptions for water supply were

217 used in the assessments. After use drinking water is considered as wastewater and is transported via

218 combined sewers to the WWTPs where it was treated before discharged to the Sea (Øresund). Electricity

219 consumption for wastewater transportation was based on average consumption in the period 2007-09

220 and processes at WWTP on consumptions from 2005-09 (Danva, 2010). 


\subsubsection{A1 Rain \& stormwater harvesting}

222 In the A1 case rain and stormwater is considered harvested from an urban area of $68,500 \mathrm{~m}^{2}$ (roof area

$22320,200 \mathrm{~m}^{2}$; main road area $8,500 \mathrm{~m}^{2}$ ) populated by 1,000 residents and 200 employees. Rainwater is

224 collected from the roofs and led to an underground basin $\left(750 \mathrm{~m}^{3}\right)$. Stormwater from the main road is

225 collected in large pipes $(\varnothing 1,000 \mathrm{~mm})$ and led to a basin established in connection with a clarifier and

226 pumping station controlling the flow. The clarifier separated oils from the water before it passes through

227 a dual porosity filter. In dual filtration stormwater floats by gravity on a solid phase consisting of layers

228 of $\mathrm{CaCO}_{3}$ particles resulting in suspended solids, heavy metals and $\mathrm{PAHs}$ in the stormwater being

229 adsorbed and thereby removed (Jensen, 2009). Afterwards the treated stormwater is mixed with

230 rainwater and stored in a basin. Prior to distribution to the same residential and office buildings as

231 where collected the water is UV-treated. The water is of non-potable quality and is used for flushing

232 toilets and washing clothes. The area is as most parts of Copenhagen drained by combined sewers and

233 the decoupling of the rain and stormwater is a significant environmental advantage of A1 as electricity

234 consumption for transport and treatment of wastewater is reduced. Rainwater is soft but since it passed

235 through a filter of $\mathrm{CaCO}_{3}$ particles the resulting hardness of the non-potable water was $145 \mathrm{mg} / \mathrm{L}$ as

$236 \mathrm{CaCO}_{3}$ (Jensen, 2009). This hardness is lower than in the drinking water in the base case (A0). Effects of

237 changed hardness levels in the households were included in the LCA, i.e. decreased consumption of

238 laundry detergent and electricity and prolonged service life of washing machine and toilets (Godskesen

239 et al., 2012).

\section{$240 \quad$ 2.3.3 A2 Compensating actions}

241 Compensating actions (case A2) cover various initiatives implemented to fulfill the requirements for

242 water flows in watercourses to maintain the current abstraction volume as described by the

243 implementation of EU-WFD. In this study compensating actions included abstraction of groundwater,

244 transfer of water from lakes to watercourses and reestablishment of wetlands from forest land (Table

245 1). Besides the various compensating actions $A 2$ included all processes in the base case (A0). Regarding 
246 calculation of the characterization factor (CF) it was assumed that HOFOR obtained permissions for

247 groundwater withdrawal equivalent to the permissions before EU-WFD resulting in a CF at

248 approximately 1.

\section{$249 \quad$ 2.3.4 A3 New well fields}

250 The new well site case (A3) is also equivalent to the base case with addition of a $20 \mathrm{~km}$ longer pipeline

251 from well fields to the waterworks. In A0 water is transported $5 \mathrm{~km}$ from well fields to waterworks. The

252 longer distance means increased energy consumption. Regarding FWI we assumed we could find well

253 fields with a surplus of available groundwater according to the EU-WFD within this distance. Therefore,

254 CF was estimated to 1.

$255 \quad$ 2.3.5 A4 Desalination

256 Copenhagen is situated at the entrance to the Baltic Sea (Øresund) and desalination of seawater is an

257 option. The treatment plant is considered to be located $5 \mathrm{~km}$ south of the city. First, water is filtrated

258 mechanically $(150 \mu \mathrm{m})$ to remove large particles, a coagulant is added and pH adjusted and the water is

259 ultra filtrated where $10 \%$ of the water is lost and returned to $\emptyset$ resund after extraction of dry material.

260 An anti scaling agent is added before the water passes through a 2 step reverse osmosis membrane and

261 hydrochloric acid and sodium hydroxide are dosed regularly to clean membranes from fouling. Finally

262 calcium hydroxide is added and the water UV treated (Rygaard, 2010). The water has a hardness of 108

$263 \mathrm{mg} / \mathrm{L}$ as $\mathrm{CaCO} 3$ when distributed as drinking water and the positive effects in the households due to the

264 lower hardness were included in the LCA as for Case A1. The effects for A4 are besides the ones

265 mentioned for A1 decreased electricity consumption when heating water (washing machine, coffee

266 maker and kettle), decreased consumption of soap for personal hygiene, etc. (Godskesen et al., 2012),

267 see Table 1 for all included effects. 
$268 \quad 2.4$ Sensitivity Analysis

269 Selected parameters were changed to check the robustness of the results for standard LCA impact

270 categories and FWI and are described in Table 2.

271 


\section{Results and Discussion}

\section{$273 \quad 3.1 \quad$ Standard LCA}

274 Selected inventory data for the 4 cases (A1-A4) and base case (A0) show relatively similar electricity 275 consumptions during use stage (Table 3) for A0, A2 and A3 $\left(3.73-4.44 \mathrm{MJ} / \mathrm{m}^{3}\right)$ whereas it was lower for $276 \mathrm{~A} 1\left(0.92 \mathrm{MJ} / \mathrm{m}^{3}\right)$ due to avoidance of discharge to the combined sewers in the area and the following 277 treatment at the WWTP. In contrast, electricity consumption $\left(7.49 \mathrm{MJ} / \mathrm{m}^{3}\right)$ was higher with desalination 278 which is in accordance with the findings of others (Vince et al., 2008; Lyons et al., 2009). A1 (rain \& 279 stormwater harvesting) had the highest material requirement per functional unit involving 280 infrastructure elements such as concrete, cast iron and plastics due to the construction of the storage 281 basins and pipes. The freshwater withdrawn to deliver the functional unit $\left(-0.0014-1.0201 \mathrm{~m}^{3}\right.$ 282 groundwater) included only groundwater and not rain, storm- or seawater, leaving freshwater 283 consumption for A1 and A4 relatively small. In our case study harvested rain \& stormwater would have 284 been included as freshwater withdrawal if it had been infiltrated into the ground (thus being part of the 285 surface- and groundwater recharge), rather than being led into combined sewers as is the current 286 practice.

287 The results of the cases differ markedly for the impact scores for the EDIP impact categories (Table 4) 288 and show that the rain \& stormwater harvesting case (A1) has the lowest total aggregated 289 environmental impact (81.9 $\mu \mathrm{PET} / \mathrm{m} 3)$. The cases relying on groundwater abstraction $(\mathrm{A} 0, \mathrm{~A} 2$ and $\mathrm{A} 3)$ 290 had an environmental impact of $123.5-137.8 \mu \mathrm{PET} / \mathrm{m} 3$. A1 had a low environmental impact mainly due 291 to the role of combined sewers and the positive effects of lower water hardness in the households.

292 Desalination has the highest total environmental impact score (204.8 $\mu \mathrm{PET} / \mathrm{m} 3)$, primarily due to the use 293 of electricity.

294 The environmental impact category with the highest importance for the 4 cases is global warming 295 potential (67-80\% of the total environmental impacts; Table 4) and this impact over the life cycle of the 
water production originates from different parts when dividing them into infrastructure and electricity

297 (Fig. 2). The contribution from water treatment is relatively higher for A1 compared to the others. The cases relying on groundwater abstraction (A0, $A 2-A 3)$ show very similar patterns with little contribution from water production and more than $50 \%$ from wastewater transport and treatment. If wastewater treatment had not been included, these 3 cases would have had the lowest impact, but then the cases would not have been comparable, since the rain \& stormwater harvesting reduced the amount of wastewater to be treated. This emphasizes the importance of a thorough assessment of proper system boundaries, functional unit, etc. in the preparation of an LCA (ISO, 2006).

\subsubsection{Effects of water hardness}

305 This study shows that a difference in water hardness of $215 \mathrm{mg} / \mathrm{L}$ as $\mathrm{CaCO}_{3}$ or higher between the systems is important to the results of the LCA (Fig. 2, negative values of A1 and A4) which is in

307 accordance with findings of a previous study (Godskesen et al., 2012). Lower water hardness reduces global warming impact of the desalination case A4 from 224.7 to $151.4 \mu \mathrm{PET}$ and the total environmental impact from 336.7 to $204.8 \mu \mathrm{PET}$ (Table 4) equivalent to approximately $40 \%$ reduction. In comparison an increase of environmental impacts of approximately $500 \%$ was found by Lyons et al. (2009) when comparing import of freshwater over a distance of $280 \mathrm{~km}$ with desalination. In spite of the energy

312 requirements of the desalination process, we found an increase of only $60 \%$ in total environmental

313 impacts when comparing desalination with our base case. This relatively small increase is mainly due to 314 the positive effects of reduced water hardness.

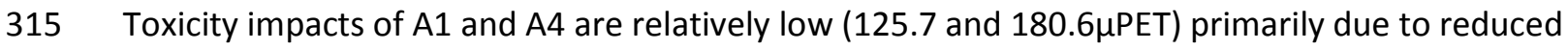
consumption of laundry detergent and prolonged service life of household appliances compared to the

317 base case (Table 4). Also consumption of chromium and copper is reduced due to prolonged service life 318 of domestic appliances and hence lower consumption of chromium for alloying of steel. These effects of 319 reduced water hardness are also the reason for the net benefit in freshwater withdrawal of A4 (Table 3) 
since it is assumed that the water extraction for manufacture of the household appliances occurs in the

321 catchment areas. Thus the systems delivering water with reduced water hardness have relatively lower

322 impacts regarding toxicity and resource consumptions even though included infrastructure materials or

323 electricity consumption are higher.

\section{$324 \quad 3.2 \quad$ Freshwater withdrawal impact (FWI)}

325 Characterization factor (CF) for the FWI of groundwater withdrawal of the base case was 1.51. When

326 either compensating the environment by water transfer to the water scarce watercourses or moving

327 well fields out where more water is available CF was reduced to 1.38 or 1.00 , respectively (Table 5). The

328 FWIs were higher for the groundwater-based cases (A0, A2 and $\mathrm{A} 3$ ) due to higher freshwater withdrawal

$329(\mathrm{Q}$, Table 3). FWI was negative for A4 meaning the case provides a net benefit in freshwater availability.

330 For comparison the withdrawal-to-availability indicator (WTA) (Milà-i-Canals et al., 2009) was applied.

331 Table 6 shows that the WTAs of our region's groundwater resources (0.48-0.61) are similar to WTA for

332 freshwater resources in Spain (0.33) suggesting that our withdrawal of groundwater is as severe as

333 withdrawal of freshwater in Spain.

\section{$334 \quad$ 3.2.1 Water stress index}

335 The base of the CF is also called the water stress index (WSI) which is also another way of determining

336 environmental water balance:

$337 \quad W S I=\frac{W U}{W R-E W R}$

(Smakhtin et al., 2004) (2)

338 WSI is categorized as presented in Table 7 (Smakhtin et al., 2004). Applying this definition to HOFOR's

339 groundwater catchments (1.73) shows that the withdrawal is categorized as environmental water scarce

340 (Table 5- 7). A WSI of 1 as for A3 implies that on average the actual water use is equivalent to the

341 utilizable freshwater volume however it still indicates environmental water stress for low flow water

342 courses in the water catchments. Aggregating catchments for a larger area (Sjælland - Copenhagen and 
nearby rural area bounded by the Sea) still results in water stress (WSI 1.37). Upscaling to national level

344 or moving to rural areas results in low CFs and WSIs $(0.05-0.28)$ indicating withdrawals which are

345 environmentally safe (Table 6). CF has previously been considered lower (0.04) for the country when

346 focusing on the entire freshwater resources (ground and surface water) (Lévová \& Hauschild, 2011). We

347 here show the necessity of downscaling since this is where we find the magnitude of the impact on the

348 local water bodies. We also see the importance of distinguishing groundwater from surface water when

349 calculating impacts of freshwater withdrawal. Surface water and groundwater are two different

350 resources which do not present the same scarcity and may not even serve the same users or purposes,

351 as also discussed by Boulay et al., (2011). Calculations of CF, WTA and WSI are shown in Supplementary

352 material II.

\section{$353 \quad 3.3 \quad$ LCA and Freshwater withdrawal impact (FWI)}

354 The contribution from FWI to the total environmental impact is substantial (-0.02 - $17.04 \mathrm{mPET})$ (Fig. 3)

355 compared to the standard impact categories $(0.08-0.20 \mathrm{mPET})$. This is a logical consequence of water

356 production being the activity which requires the highest withdrawal of groundwater whereas many

357 other processes in our daily life such as transportation and heating of houses contribute markedly more

358 to other impact categories e.g. global warming. The average drinking water consumption is $38 \mathrm{~m}^{3} / \mathrm{p} / \mathrm{y}$

359 and the annual groundwater withdrawal of the region is $70 \mathrm{~m}^{3} / \mathrm{p} / \mathrm{y}$ since groundwater is also used for

360 industrial and agricultural purposes. The high impact of FWI underlines the importance of incorporating

361 impacts on freshwater in the decision making process within the water sector and is in accordance with

362 the global trend of considering water consumption a matter of high priority (Gleick, 2009; European

363 Environment Agency, 2012).

364 We also show that the methods previously used on national levels can be applied to local water

365 catchments and can be integrated into the standard LCA method as an impact category (Fig. 3) focusing

366 on the relevant local source. Including the FWI in the LCA (Fig. 3) changed the ranking of the cases 
compared to the ranking by the standard LCA. The rain \& stormwater case (A1) continues to have lowest

368 impact and the desalinated seawater (A4) goes from being the highest environmental burden to the 369 second lowest when including FWI. The cases relying on groundwater (A0, A2 and A3) obtain a higher

370 impact due to the heavy withdrawal of groundwater which after delivery and use in the urban area is

371 treated at the WWTP and discharged into the Sea. If reclaimed wastewater is returned to restore natural

372 flows it would have changed the impact of the cases.

\section{Sensitivity analysis}

374 The results from the standard LCA and FWI are relatively robust as they do not change much when

375 altering most of the selected parameters in the sensitivity analysis (Fig. 4). However future predictions

376 of changes in electricity mix significantly decreased the environmental impacts of a standard LCA when

377 the renewable share of the energy mix was increased. The sensitivity analysis clearly states that with an

378 energy mix in 2050 consisting of $100 \%$ renewables the A4 desalination of seawater has the lowest

379 impact compared to groundwater based technologies with high water hardness and no central softening

380 applied. However, this change in water production will lead to an overall increased energy consumption

381 which is unfavorable in terms of environmental impacts unless it is based on surplus electricity from the

382 grid. We also see that in 2050 rain \& stormwater harvesting is less favorable due to the electricity

383 needed to build large concrete basins for storage since our model contains basins constructed with

384 electricity mix of today. We find that changing the EWR from 65 to $35 \%$ halves the impact of the FWI.

385 EWR is in our study somewhat arbitrary since it has been predetermined by authorities without

386 considerations of local conditions. However, it does not change the fact that whether EWR is low or high

387 the FWI category is significantly higher than the standard LCA categories and therefore is essential to 388 include in our LCA (Fig. 4). 
389

390

391

392

393

\section{Conclusion}

This study extended the standard LCA method with the impact of freshwater withdrawal by further developing an existing method which was originally developed for assessing industrial freshwater use at a regional scale. We applied the method to the water supply system of Copenhagen where the EU-WFD puts restrictions on the available local groundwater resources. The main findings of this work include:

- We developed and implemented a method to integrate freshwater withdrawal impact (FWI) into the standard LCA by applying a method previously used on national levels to the relevant local water catchments. The integration emphasizes the high importance of FWI, even when choosing the weakest weighting according to the distance-to-political-target method, compared to standard LCA categories especially within the water production sector.

- Integrating freshwater withdrawal impact assessment into the standard LCA categories resulted in the cases rain \& stormwater harvesting (A1) and desalination of seawater (A4) (0.09 and 0.18 $\mathrm{mPET} / \mathrm{m}^{3}$ ) had the lowest impact compared to the cases based on groundwater resources $\left(11.45-17.16 \mathrm{mPET} / \mathrm{m}^{3}\right)$ and this is due to a scarcity of groundwater considering the amount of available groundwater and water withdrawal in this region.

- The standard LCA showed that the rain \& stormwater harvesting case (A1) has the lowest environmental impact $\left(81.9 \mu \mathrm{PET} / \mathrm{m}^{3}\right)$ followed by the cases relying on groundwater abstraction (123.5-137.8 $\left.\mu \mathrm{PET} / \mathrm{m}^{3}\right)$, and that A4 desalination $\left(204.8 \mu \mathrm{PET} / \mathrm{m}^{3}\right)$ has a noteworthy increase in environmental impact. If the rain \& stormwater is not harvested it is led to combined sewers where e.g. energy is consumed to transport and treat the wastewater. Therefore, it is environmentally beneficial mainly due to energy savings to prevent precipitation from discharging into the sewers e.g. by harvesting and recycling for non-potable purposes.

- It is also essential to include the beneficial effects of reduced water hardness in households when comparing the environmental impacts of water supply cases leading to water of different 
hardness. Especially for desalination of seawater the reduced water hardness reduces the environmental impacts of our standard LCA by approximately $40 \%$.

$415 \quad-\quad$ The sensitivity analysis indicated that if we have to rethink the water supply in the year 2050 with an electricity mix of $100 \%$ renewable sources desalination of seawater (A4) has the lowest environmental impact when it comes to the standard LCA and FWI, provided that renewable electricity sources will be able to meet the increased electricity use that would result from a major shift towards desalination in the drinking water supply.

\section{Acknowledgements}

422 The Ministry of Science, Technology and Innovation in Denmark funded the Industrial PhD in which 423 this research was done and which was a member of Urban Water Tech Graduate School. The help of $424 \quad$ Lisbet Brusendorff for improving the graphics is also gratefully acknowledged. 
427 Boulay A., Bulle C., Bayart J., Deschênes L. \& Margni M. (2011). Regional Characterization of Freshwater $428 \quad$ Use in LCA: Modeling Direct Impacts on Human Health. Environ Sci Technol. 45(20), 8948-8957.

Danish Geological Survey (2012). The Jupiter Database, http://www.geus.dk/jupiter/index-dk.htm.

Danish Ministry of Climate, Energy and Building (2012). Energy agreement. http://www.kemin.dk/enUS/Climate and energy policy/Denmark/energy agreements/Sider/Forside.aspx.

432

Danish Nature Agency (2011). Vandplan 2010-2015 (eng.: River Basin Management Plan 2010-2015). Isefjord og Roskilde Fjord. Hovedopland 2.2. Vanddistrikt Sjælland. ISBN nr. 978-87-7279-361-0.

Danva (2010). Udviklingen i spildevandsselskabernes energiforbrug 2005-2009 (eng.: Development of Energy consumption at the wastewater treatment plants 2005-2009). Danva, Dansk vand- og spildevandsforening.

Energinet.dk (2010). Energi 2050. Udviklingsspor for energisystemet (eng.: Energy 2050. Development track for the energy system). www.energinet.dk.

European Environment Agency (2012). Towards efficient use of water resources in Europe, ISSN 17259177, Copenhagen, Denmark.

European Environment Agency (2007). Water Stress in Europe, 2000 and 2030 http://www.eea.europa.eu/data-and-maps/figures/water-stress-in-europe-2000-and-2030.

European Union (2000). The Water Framework Directive (Directive 2000/60/EC of the European Parliament and of the Council of 23 October 2000 establishing a framework for Community action in the field of water policy).

Gleick P. H. (2009). The World's Water 2008-2009 / The biennial report on freshwater resources. Island Press, Washington,DC.

Gleick P. H. (2000). The World's water 2000-2001 / The biennial report on freshwater resources. Island Press, Washington,DC.

Godskesen B., Hauschild M. Z., Rygaard M., Zambrano K. C. \& Albrechtsen H. J. (2012). Life cycle assessment of central softening of very hard drinking water. Journal of environmental management. 105, 83-89.

Godskesen B., Zambrano K. C., Trautner A., Johansen N. B., Godskesen B., Rygaard M., Albrechtsen H. J., Johansen N. B., Thiesson L., Andersen L., Clauson-Kaas J., Neidel T. L., Andersen L., Clauson-Kaas J., Neidel T. L. \& Kløverpris N. H. (2011). Life cycle assessment of three water systems in Copenhagen-a management tool of the future. Water Sci Technol. 63(3), 565-572.

Hauschild M. Z. \& Potting J. (2005). Spatial differentiation in life cycle impact assessment - the EDIP-2003 methodology. Guidelines from the Danish EPA, Copenhagen, Denmark. 
Hoekstra A. Y., Chapagain A. K., Aldaya M. M. and Mekonnen M. M. (2011). The water footprint assessment manual:

Setting the global standard, ISBN: 978-1-84971-279-8, Earthscan.

ISO (2006). Environmental management - Life Cycle Assessment - Requirements and guidelines - ISO 14044, ISO 14044:2006, European Committee for Standards, rue de Stassart, 36, B-1050 Brussels.

Jensen M. B. (2009). Basisrapport: Dobbeltporøs filtrering. Pilotafprøvning - Rensning af vejvand i $\varnothing$ restad. Hændelse 1-25, januar - juli 2007 (eng.: Double Porous Filter - Pilot project). KU Life. Denmark.

Kounina A., Margni M., Bayart J., Boulay A. -., Berger M., Bulle C., Frischknecht R., Koehler A., Milà-iCanals L., Motoshita M., Nuñez M., Peters G., Pfister S., Ridoutt B., van Zelm R., Verones F. \& Humbert S. (2012). Review of methods addressing freshwater use in life cycle inventory and impact assessment. International Journal of Life Cycle Assessment. (DOI 10.1007/s11367-012-0519-3).

Lévová T. \& Hauschild M. Z. (2011). Assessing the impacts of industrial water use in life cycle assessment. CIRP annals. 60(1), 29-32.

Lundie S., Peters G. M. \& Beavis P. C. (2004). Life Cycle Assessment for Sustainable Metropolitan Water Systems Planning. Environ Sci Technol. 38(13), 3465-3473.

Lyons E., Zhang P., Benn T., Sharif F., Costanza M., Li K., Crittenden J. \& Chen Y. S. (2009). Life cycle assessment of three water supply systems: Importation, reclamation and desalination. Water Sci Technol Water Supply. 9(4), 439-448.

Milà-i-Canals L., Chapagain A., Orr S., Chenoweth J., Anton A. \& Clift R. (2010). Assessing freshwater use impacts in LCA, part 2: case study of broccoli production in the UK and Spain. Int J Life Cycle Assess. 15(6), 598-607.

Milà-i-Canals L., Chenoweth J., Chapagain A., Orr S., Ant Ã³n A. \& Clift R. (2009). Assessing freshwater use impacts in LCA: Part 1: inventory modelling and characterisation factors for the main impact pathways. Int J Life Cycle Assess The international journal of life cycle assessment. 14(1), 28-42.

Muñoz I., Mila-i-Canals L. \& Fernández-Alba A. R. (2010). Life Cycle Assessment of Water Supply Plans in Mediterranean Spain: The Ebro River Transfer Versus the AGUA Programme. J Ind Ecol. 14(6), 902918.

Pfister S., Koehler A. \& Hellweg S. (2009). Assessing the environmental impacts of freshwater consumption in LCA. Environmental Science and Technology. 43(11), 4098-4104.

Rygaard M. (2010). Desalinated water in urban water supplies - a systems approach to identify optimal drinking water composition. PhD Thesis, Technical University of Denmark (DTU Env).

Schulz M., Short M. D. \& Peters G. M. (2012). A streamlined sustainability assessment tool for improved decision making in the urban water industry. Integrated Environmental Assessment and Management. 8(1), 183-193. 
Sharma A. K., Grant A. L., Grant T., Pamminger F. \& Opray L. (2009). Environmental and Economic Assessment of Urban Water Services for a Greenfield Development. Environ Eng Sci. 26(5), 921-934.

Smakhtin V., Revenga C. \& Doll P. (2004). A pilot global assessment of environmental water requirements and scarcity. Water Int. 29(3), 307-317.

Statistics Denmark (2012). Population statistics. http://www.danmarksstatistik.dk/da/Statistik/emner/befolkning-ogbefolkningsfremskrivning/folketal.aspx.

Stranddorf H. K., Hoffmann L. and Schmidt A. (2005). Update on Impact Categories, Normalisation and Weighting in LCA. Guidelines from the Danish EPA, Copenhagen, Denmark.

US Geological Survey (2012). Water hardness and alkalinity, http://water.usgs.gov/owq/hardnessalkalinity.html.

Vince F., Aoustin E., Bréant P. \& Marechal F. (2008). LCA tool for the environmental evaluation of potable water production. Desalination. 220(1-3), 37-56.

Wenzel H, Hauschild MZ, Alting L (1997) Environmental asessment of products - 1: Methodology, tools and case studies in product development. In: Kluwer Academic Publishers, Hingham, MA. USA, Chapman \& Hall, United Kingdom.

Zelm R. v., Schipper A. M., Rombouts M., Snepvangers J. \& Huijbregts M. A. J. (2010). Implementing Groundwater Extraction in Life Cycle Impact Assessment: Characterization Factors Based on Plant Species Richness for the Netherlands. Environ Sci Technol. 45(2), 629-635. 


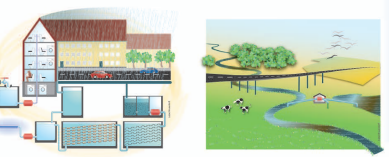

$=7$
Life-cycle

freshwater withdrawal assessment

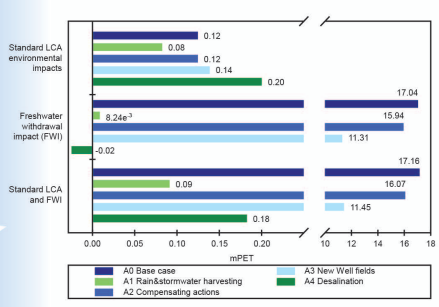


Groundwater,

Rain or Sea

water

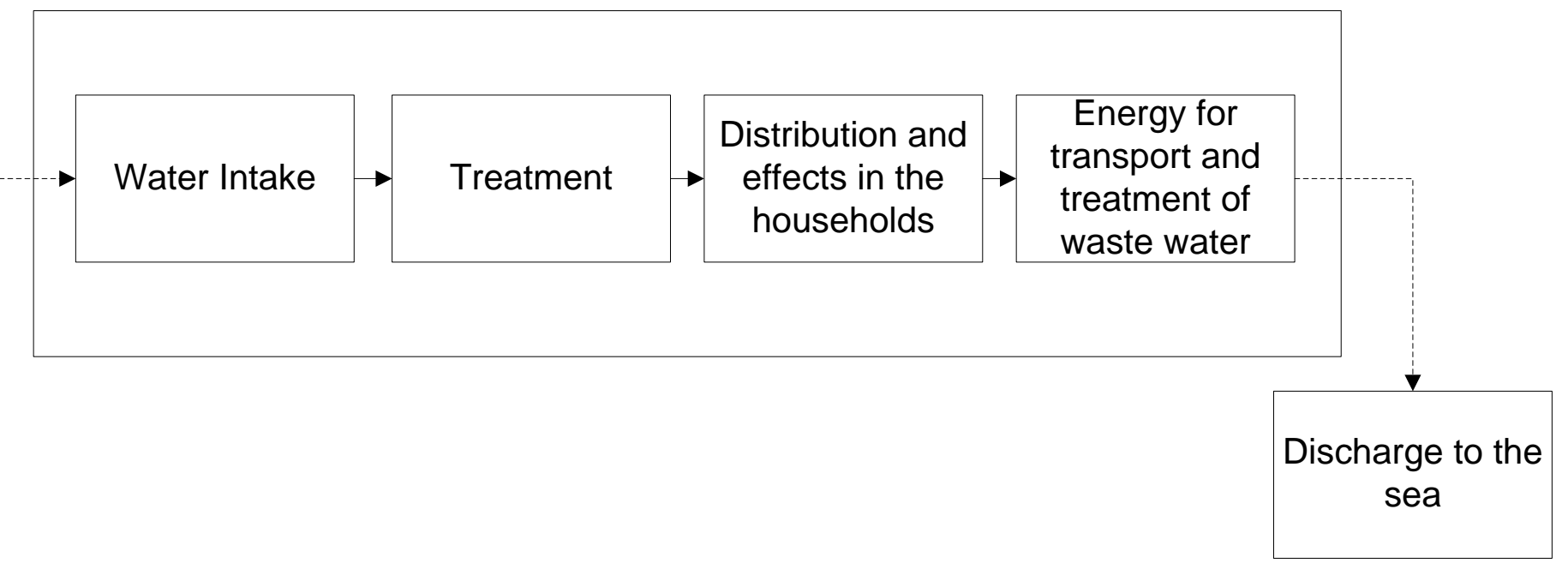


A1 Rain \& stormwater harvesting A2 Compensating
actions

A3 New well fields A4 Desalination

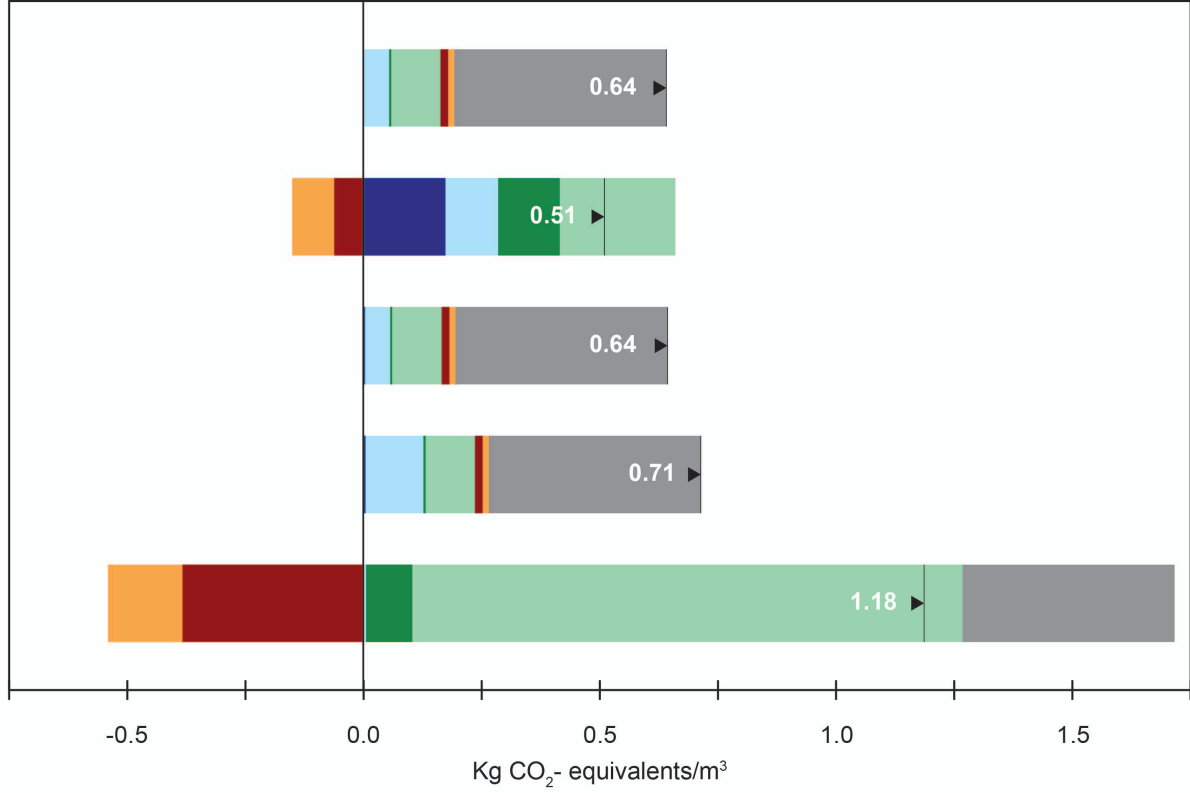


Standard LCA environmental impacts

Freshwater withdrawal impact (FWI)

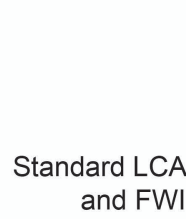
and FWI

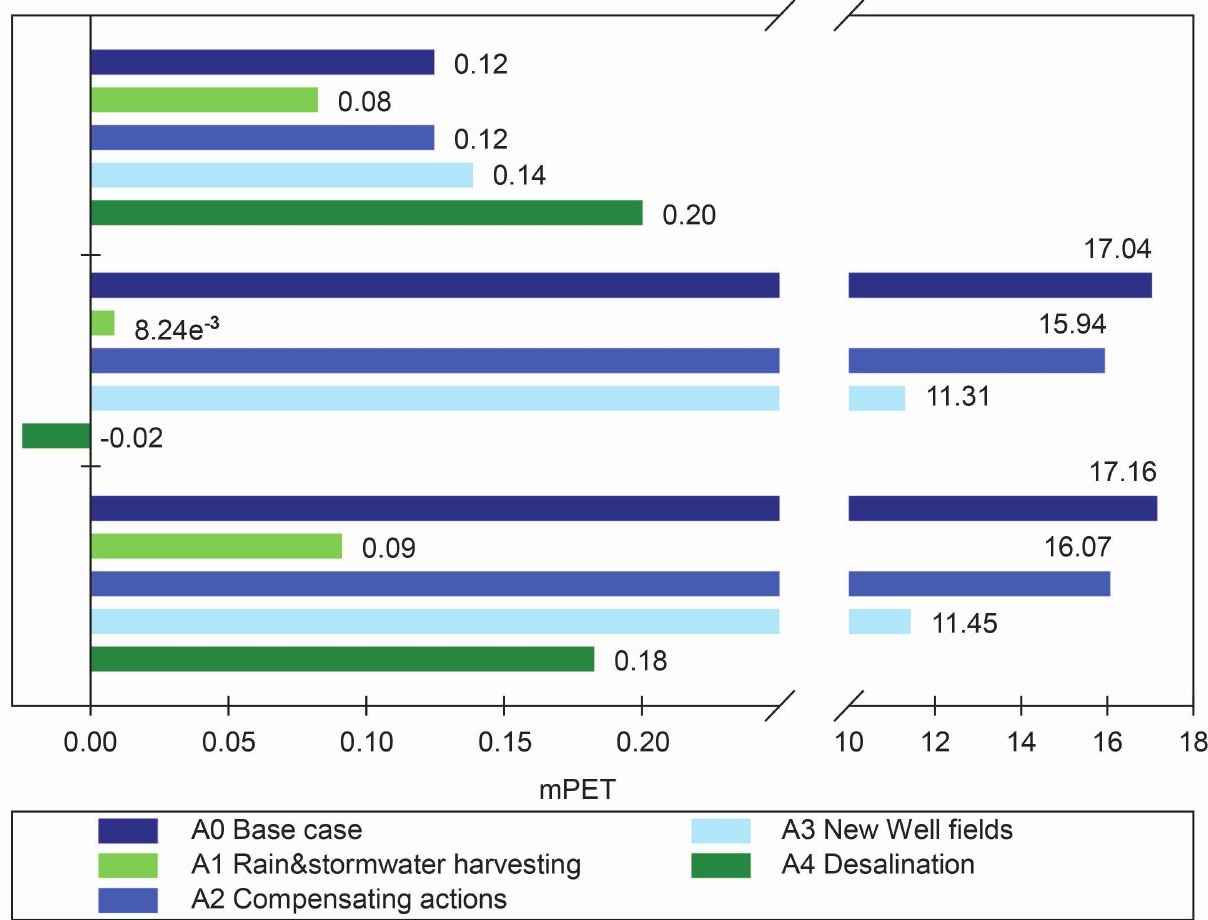




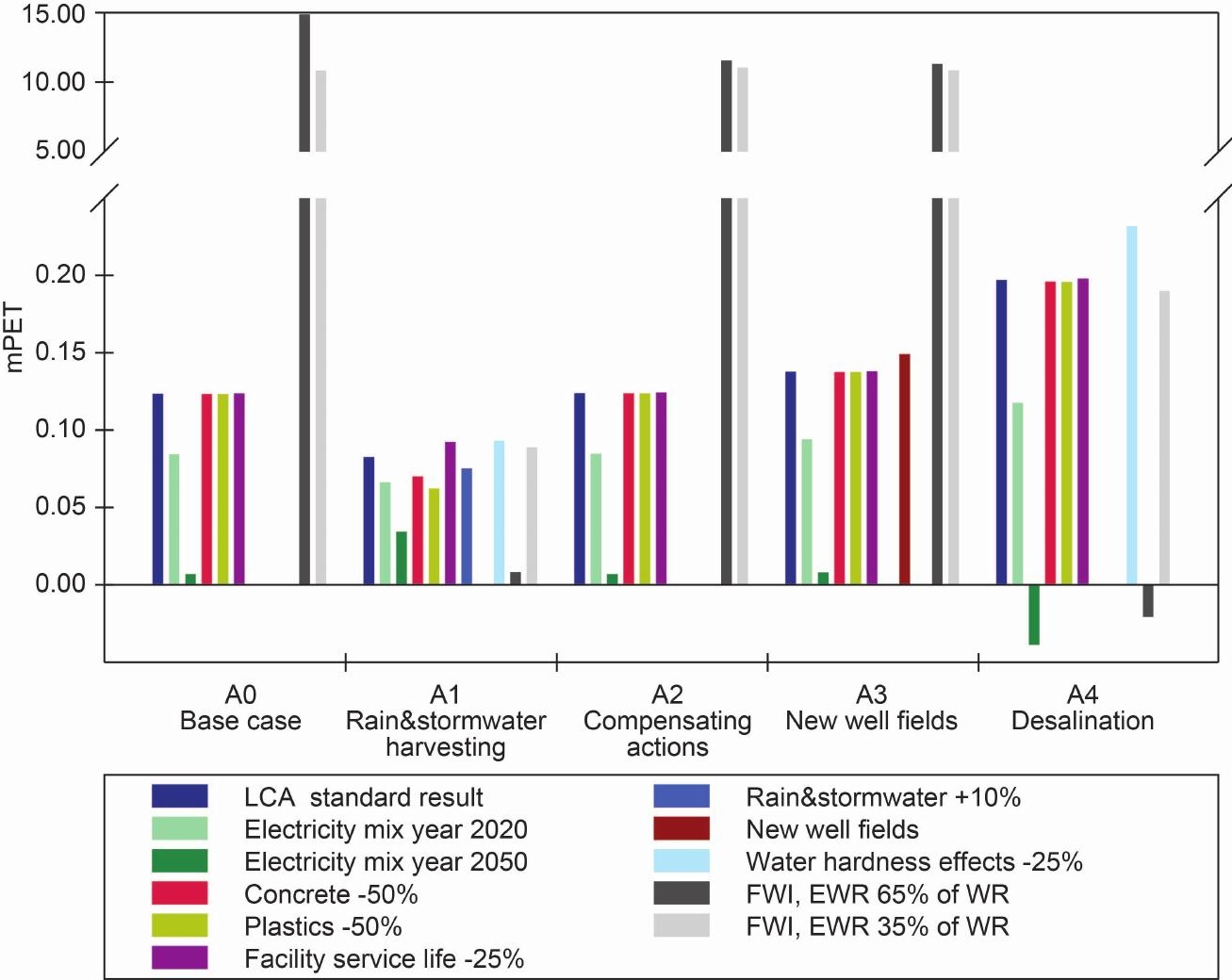




\begin{tabular}{ll}
\hline List of Abbreviations & \\
\hline CE & Copenhagen Energy (water utility) \\
CF & Characterization factor \\
EU-WFD & European Union Water Framework Directive \\
EWR & Environmental water requirements \\
FWI & Freshwater withdrawal impact \\
LCA & Life-cycle assessment \\
WR & Renewable water resource \\
WSI & Water stress index \\
WTA & Withdrawal to availability ratio \\
WU & Water use \\
WWTP & Wastewater treatment plant \\
\hline
\end{tabular}


Table 1. Processes included in the LCA modeling of the cases: A0 Base case; A1 Rain- \& stormwater harvesting; A2 Compensating actions; A3 Building well fields $20 \mathrm{~km}$ further away; A4 Desalination of seawater. Processes are structured into the categories Water intake method, Treatment, Distribution and effects in the households and Transport and treatment of wastewater. See supplementary material for specific data.

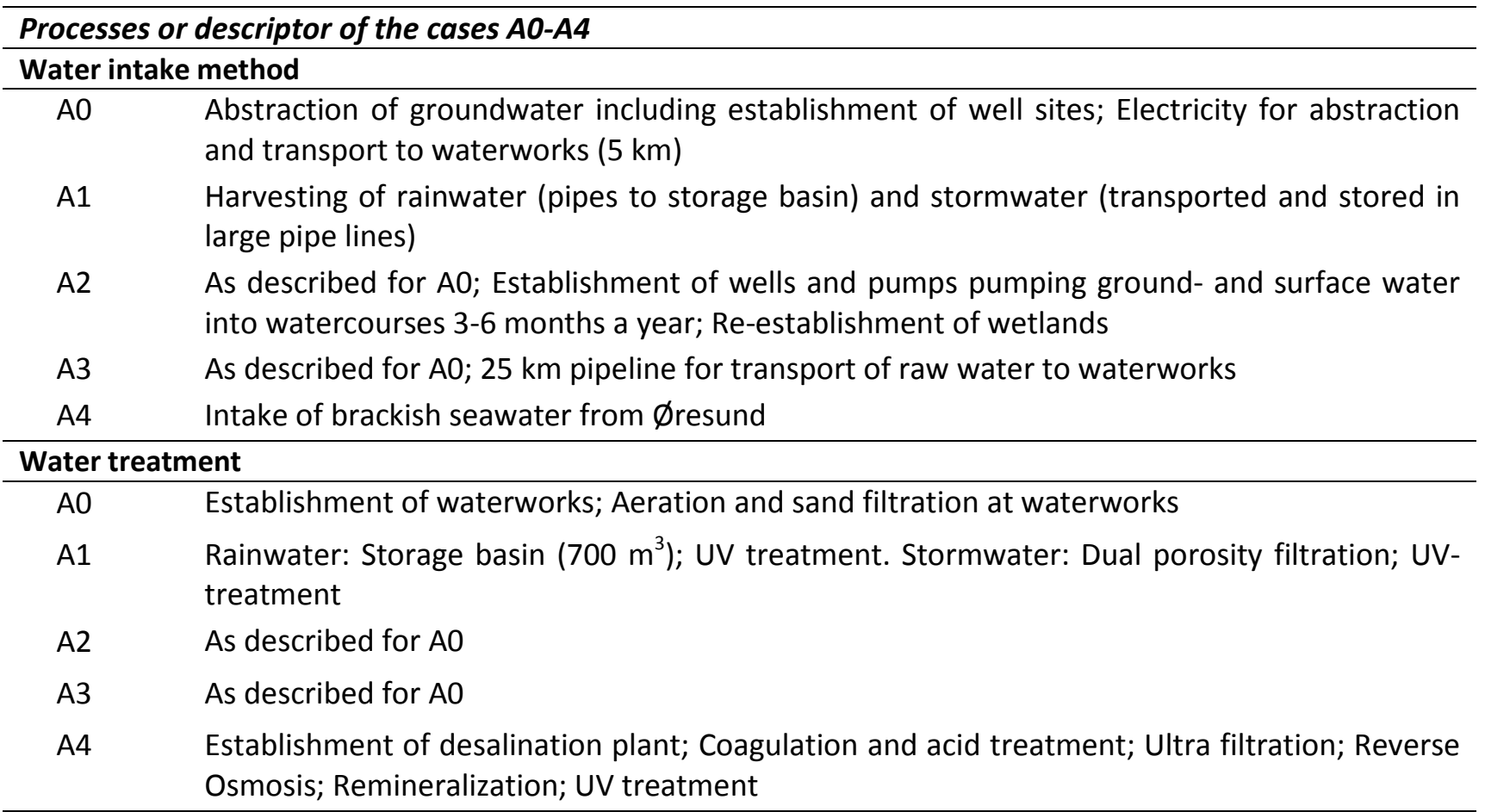

Distribution of water and effects in the households

A0 Establishment of the existing piped distribution system from waterworks to tap; Water hardness $362 \mathrm{mg} / \mathrm{L}_{\text {as }} \mathrm{CaCO}_{3}$ - effects in households are considered zero-effect

A1 Piped distribution system from basin to tap; Water hardness of $145 \mathrm{mg} / \mathrm{L}$ as $\mathrm{CaCO}_{3}$ - effects in households leading to decreased consumption of laundry detergent, prolonged service life of washing machine and toilets

A2 As described for A0

A3 As described for $\mathrm{AO}$

A4 Establishment of the existing piped distribution system from plant to tap; Water hardness of $108 \mathrm{mg} / \mathrm{L}$ as $\mathrm{CaCO}_{3}$ - effects in households leading to decreased consumption of: Soap for personal hygiene; Laundry detergent; Electricity consumption (washing machine, coffee maker and kettle); Soap for doing dishes by hand and Salt for regeneration of ion exchanger fitted on dishwasher; Prolonged service life: Washing machine; Dishwasher; Coffee maker; Kettle and Toilets; More energy efficient district heating

Transport and treatment of wastewater and rain

A0, A2, Pumped via combined sewer system to the wastewater treatment plant before discharged to A3 \& A4 the Sea (Øresund). Energy consumption is included for wastewater processes.

A1 Rain- \& stormwater is harvested and prevented from entering combined sewer system 
Table 2. Parameters included in the sensitivity analysis.

\begin{tabular}{|c|c|}
\hline $\begin{array}{l}\text { Parameters changed in the } \\
\text { sensitivity analysis }\end{array}$ & Description of the change of parameter \\
\hline \multirow{2}{*}{$\begin{array}{l}\text { Electricity mix according to } \\
\text { future political plans }\end{array}$} & In the year $202050 \%$ of the electricity comes from renewable sources \\
\hline & $\begin{array}{l}\text { In the year } 2050 \text { 100\% of the electricity comes from renewable sources } \\
\text { (Energinet.dk, 2010; Danish Ministry of Climate, Energy and } \\
\text { Building, 2012) }\end{array}$ \\
\hline $\begin{array}{l}\text { Use of concrete for } \\
\text { infrastructure material }\end{array}$ & Materials reduced by $50 \%$ \\
\hline $\begin{array}{l}\text { Use of plastic for infrastructure } \\
\text { material }\end{array}$ & Materials reduced by $50 \%$ \\
\hline Service life of facilities & Reduced by $25 \%$ as assets might be changed before necessary \\
\hline $\begin{array}{l}\text { Harvested volumes of rain- and } \\
\text { stormwater }\end{array}$ & Increased by $10 \%$ in accordance with predictions for rainfall (case A1) \\
\hline Efficiency of water transport & $\begin{array}{l}65 \% \text { less energy efficient in accordance with estimations of CE for } \\
\text { aged well fields (case A3) }\end{array}$ \\
\hline $\begin{array}{l}\text { Effects of reduced water } \\
\text { hardness }\end{array}$ & Effects in the households reduced by $25 \%$ \\
\hline $\begin{array}{l}\text { Environmental water } \\
\text { requirements (EWR) }\end{array}$ & $\begin{array}{l}\text { Reduced from the national figure of } 65 \% \text { (Danish Nature Agency, } \\
\text { 2011) to } 35 \% \text { of WR in accordance with other findings of international } \\
\text { water catchments (Smakhtin et al., 2004; Pfister et al., 2009) }\end{array}$ \\
\hline
\end{tabular}

Table 3. Inventory data for selected materials and electricity use for the cases in this study: A0 Base case; A1 Rain- \& stormwater harvesting; A2 Compensating actions; A3 Building well fields 20km further away; A4 Desalination of seawater All parameters are given per functional unit, deliverance of $1 \mathrm{~m}^{3}$ of water.

\begin{tabular}{|c|c|c|c|c|c|}
\hline & $\begin{array}{r}\text { A0 } \\
\text { Base case }\end{array}$ & $\begin{array}{r}\text { A1 } \\
\text { Rain \& } \\
\text { stormwater } \\
\end{array}$ & $\begin{array}{r}\mathrm{A} 2 \\
\begin{array}{r}\text { Compensating } \\
\text { actions }\end{array} \\
\end{array}$ & $\begin{array}{r}\text { A3 } \\
\text { New well } \\
\text { fields } \\
\end{array}$ & $\begin{array}{r}\text { A4 } \\
\text { Desalination }\end{array}$ \\
\hline \multicolumn{6}{|c|}{ Direct Electricity consumption, MJ (use stage) } \\
\hline & 3.7248 & 0.9180 & 3.7559 & 4.4410 & 7.4921 \\
\hline \multicolumn{6}{|l|}{ Concrete, $k g$} \\
\hline & 0.0080 & 0.4833 & 0.0080 & 0.0080 & 0.0458 \\
\hline \multicolumn{6}{|c|}{ Cast iron \& steel, $\mathrm{kg}$} \\
\hline \multicolumn{6}{|l|}{ Plastics, kg } \\
\hline \multicolumn{6}{|c|}{ Freshwater withdrawal, $\mathbf{Q}$ (ground and surface water), $m^{3}$} \\
\hline & 1.0010 & 0.0006 & 1.0201 & 1.0011 & -0.0014 \\
\hline
\end{tabular}


Table 4. Normalized and weighted impact scores per $1 \mathrm{~m}^{3}$ water delivered by the 4 cases, grouped after Environmental impacts, Toxicity impacts and Resource consumption.

\begin{tabular}{lccrrr}
\hline & $\begin{array}{r}\text { A0 } \\
\text { Base case }\end{array}$ & $\begin{array}{r}\text { A1 } \\
\text { Rain\&storm } \\
\text {-water }\end{array}$ & $\begin{array}{r}\text { A2 } \\
\text { Compensati } \\
\text { ng Actions }\end{array}$ & $\begin{array}{r}\text { A3 } \\
\text { New well } \\
\text { fields }\end{array}$ & $\begin{array}{r}\text { D4 } \\
\text { Desalination }\end{array}$ \\
\hline Environmental impacts, $\boldsymbol{\mu P E T}$ (Person Equivalent Targeted, weighted result) \\
\hline Total environmental imp. & 123.5 & 81.9 & 123.9 & 137.8 & 204.8 \\
Global Warming & 82.5 & 65.5 & 82.8 & 91.9 & 151.4 \\
Acidification & 24.6 & 10.3 & 24.7 & 27.5 & 36.3 \\
Nutrient enrichment & 14.5 & 7.6 & 14.5 & 16.2 & 23.6 \\
Photochem. ozone form. & 1.9 & -1.5 & 1.9 & 2.2 & -6.5 \\
\hline Toxicity impacts, $\boldsymbol{\mu P E T ~ ( P e r s o n ~ E q u i v a l e n t ~ T a r g e t e d , ~ w e i g h t e d ~ r e s u l t ) ~}$ & & \\
\hline Total toxicity imp. & 176.0 & 125.7 & 180.3 & 193.7 & 180.6 \\
Ecotoxicity water chronic & 63.7 & 24.9 & 64.8 & 70.1 & 85.7 \\
Human toxicity soil & 69.9 & 69.8 & 70.3 & 78.7 & 58.8 \\
Human toxicity water & 42.4 & 31.0 & 45.2 & 44.9 & 36.1 \\
\hline Resource consumption, $\boldsymbol{\mu P R}$ (Person Reserve) & & & & \\
\hline Chromium & 17.3 & -34.1 & 17.4 & 17.3 & -38.3 \\
Copper & $5.6 \mathrm{E}-02$ & -3.0 & $5.7 \mathrm{E}-02$ & $6.3 \mathrm{E}-02$ & -5.3 \\
Hard coal & 2.6 & 1.2 & 2.6 & 2.9 & 5.1 \\
Natural gas & 1.7 & 1.1 & 1.7 & 1.9 & 2.4 \\
\hline
\end{tabular}

Table 5. Freshwater withdrawal impact (FWI) results. The characterization factors (CF) are calculated for the groundwater catchments where water is withdrawn. Water stress index (WSI) according to Smakhtin et al. (2004). For A4 FWI is -0.026 . *WSI is calculated for water used to establish case A1 and A4.

\begin{tabular}{lrrr}
\hline & $\begin{array}{r}\text { Characterization } \\
\text { factor (CF) }\end{array}$ & $\begin{array}{r}\text { Freshwater } \\
\text { withdrawal } \\
\text { impact (FWI) } \\
\text { [mPET] }\end{array}$ & $\begin{array}{r}\text { Water } \\
\text { stress } \\
\text { index } \\
\text { (WSI) }\end{array}$ \\
\hline Alternatives for water supply & 1.51 & 17.04 & 1.73 \\
A0, Base case & 1.51 & 0.01 & $* 1.73$ \\
A1, Rain-\&stormwater harvesting & 1.38 & 15.94 & 1.55 \\
A2, Compensating actions & 1.00 & 11.31 & 1.00 \\
A3, New well fields & 1.51 & $<0.00$ & $* 1.73$ \\
A4, Desalination & & &
\end{tabular}


Table 6. Calculation of Characterization Factors (CF) (Lévová \& Hauschild, 2011) and Withdrawal to availability ratio (WTA) (Milà-i-Canals et al., 2009) for water withdrawal scaled according to regional groundwater catchments or international regions for freshwater (ground- and surface water).

\begin{tabular}{|c|c|c|c|}
\hline Chara & $\begin{array}{l}\text { zation } \\
\text { or (CF) }\end{array}$ & $\begin{array}{r}\text { Withdrawal to } \\
\text { availability } \\
\text { (WTA) }\end{array}$ & $\begin{array}{c}\text { Water stress } \\
\text { index (WSI) }\end{array}$ \\
\hline \multicolumn{4}{|l|}{ Local groundwater catchments, Urban area } \\
\hline Copenhagen (CE's area) (app. 3,000 km²) & 1.51 & 0.61 & 1.73 \\
\hline Århus ${ }^{1}\left(772 \mathrm{~km}^{2}\right)$ & 1.36 & 0.52 & 1.49 \\
\hline \multicolumn{4}{|l|}{ Local groundwater catchments, Rural area } \\
\hline Vidå-Kruså & 0.38 & 0.10 & 0.28 \\
\hline Bornholm & 0.11 & 0.02 & 0.05 \\
\hline \multicolumn{4}{|l|}{ Larger scale groundwater catchments } \\
\hline Sjælland $(7,450$ km² incl. Copenhagen) & 1.27 & 0.48 & 1.37 \\
\hline Denmark $\left(43,000 \mathrm{~km}^{2}\right)$ & 0.34 & 0.09 & 0.25 \\
\hline \multicolumn{4}{|c|}{ International regions based on freshwater (Lévová \& Hauschild, 2011) } \\
\hline Denmark & 0.04 & 0.04 & 0.07 \\
\hline Spain & 0.42 & 0.33 & 0.52 \\
\hline Egypt & 1.10 & 0.79 & 1.05 \\
\hline
\end{tabular}

Table 7. Categorization of water stress index (WSI) determining the condition of the freshwater system (modified according to Smakhtin et al., 2004).

\begin{tabular}{ll}
\hline WSI & Categorization \\
\hline$>1.0$ & Environmental water scarce \\
$0.6-1.0$ & Environmentally water stressed \\
$0.3-0.6$ & Moderately exploited \\
$<0.3$ & Environmentally safe \\
\hline
\end{tabular}

Figure 1. System boundaries for all 4 cases illustrating the stages included in the LCA. The study included the urban water cycle from water intake and treatment over distribution and effects of water hardness to wastewater transport and treatment.

Figure 2. Distribution over the life cycle of processes contributing to Global warming potential for the 4 cases for water supply. 
Figure 3. Weighted impact results for standard LCA environmental impacts and FWI for the base case and 4 alternative cases for water supply. The lower bars are the result from a standard LCA, followed in the middle by FWI and at the top the sum of the LCA and FWI.

Figure 4. Results of the sensitivity analysis on Total environmental impact of the 4 cases for selected parameters. The parameters "More rain, $+10 \%$ "; "New well sites, $65 \%$ Energy for transportation" and "Effects of soft water reduced 25\%" were only calculated for A1, A3 and A1 and A4 respectively as the parameters only had an effect for these specific cases. 